\title{
The Modified Baumol Equation: Theory and Evidence
}

\author{
Tchai Tavor ${ }^{1}$, Limor D. Gonen ${ }^{2}$, Michal Weber ${ }^{3,4}, \&$ Uriel Spiegel ${ }^{4,5,6}$ \\ ${ }^{1}$ Department of Economics and Management, Yezreel Valley College, Yezreel Valley, Israel \\ ${ }^{2}$ Department of Economics and Business Administration, Ariel University, Israel \\ ${ }^{3}$ Faculty of Business Administration, Ono Academic College, Kiriat Ono, Israel \\ ${ }^{4}$ Department of Management, Bar-Ilan University, Ramat Gan, Israel \\ ${ }^{5}$ Department of Economics, University of Pennsylvania, Philadelphia, USA \\ ${ }^{6}$ Zefat College, Zefat, Israel \\ Correspondence: Michal Weber, Faculty of Business Administration, Ono Academic College, Kiriat Ono, Israel. \\ \& Department of Management, Bar-Ilan University, Ramat Gan, Israel. E-mail: weberm@ biu.ac.il
}

Received: November 29, 2017 Accepted: December 20, 2017 Online Published: January 9, 2018

doi:10.5539/res.v10n1p25

URL: https://doi.org/10.5539/res.v10n1p25

\begin{abstract}
Baumol developed an equation of demand for money for the transaction motive. It is affected positively by cost per withdrawal and negatively by the interest loss resulting from holding cash. The present paper suggests modifying the basic and simplified Baumol approach by adding another element to the transaction equation. Availability of cash encourages spontaneous purchases resulting in customer losses. Through cost minimization with respect to three elements instead of two as in the original Baumol equation, a new modified Baumol equation was created. It is examined by using an empirical data set and the results support the modified version of the Baumol equation. Customers respond positively to cash availability when they spend more on luxury goods. This is prominent especially among unmarried and most likely young customers. Due to high-income elasticity, spontaneous purchasing is higher among wealthier customers and full-time workers who maintain a steady and secure employment position. Since such customers have a weakness for spontaneously and sometimes even carelessly buying luxury items, from their point of view they create a good and efficient buffer by decreasing the available cash in hand and thereby reducing or possibly even preventing their wasteful behavior. The new version is robust and statistically more significant than the original equation presented in 1952.
\end{abstract}

Keywords: Baumol equation, Liquidity, Yields, Transactions, Spontaneous purchases

\section{Introduction}

Innovative payment instruments can reduce the holding of cash since they speed up the payment process at the point of sale and as a result increase the opportunity cost of cash withdrawals. Moreover, innovative payment instruments incorporate technologies which protect holders from risks of loss and theft and reduce the relative value of cash. The development of ATM networks reduces the cash withdrawal cost and therefore enables the customer to increase the frequency of withdrawals and reduce the total amount at each withdrawal. Increasing the number of ATMs and the proximity among them decreased the cost of cash withdrawals as compared to the cost of withdrawing cash at bank counters. In accordance with the formal model of Whitesell (1989), a decrease in withdrawal costs may positively affect the number of withdrawals and, in turn, the use of cash for transactions.

In the two papers referred to below, the authors depart for different reasons from the simple "square root law" of Baumol (1952). Bounie and François (2008) add the aspects of ATM networks. Bounie and François (2008) contributed to the empirical literature on the demand for money by using a direct measurement of the determinants of cash holding and by integrating new explanatory variables such as ATM surcharge and risk. The results of the papers confirm large economies of scale in cash holding for individuals who exclusively withdraw cash from an ATM machine or at a bank counter. The findings show that the presence of a surcharge increases the total individual cash holding. However, the subjective measure of risk related to cash seems to have little impact on cash holding, even though the probability of withdrawing cash at a bank counter decreases.

The phenomenon that has very often been observed in recent years is the tendency of people to avoid or sometimes even to totally eliminate the use of credit cards. This is seen more frequently, especially among people in the median income group. Their justification in most cases is that credit cards encourage them to spend uncontrollably and spontaneously on 
unimportant purchases and thus cause them to spend beyond their planned budget. For the same reason, one can see population groups including children or even young students who do not yet have credit cards but may lose control of other payments or liquid payment tools. This again encourages them to carelessly spend their available money on superfluous purchases.

For certain people, the relationship between holding cash and their actual purchases or transactions impacts them in two different ways. On one hand, the more they complete daily sales transactions or purchases, the more they need methods of payment such as credit cards, debit cards or cash and deposits. However, holding more available liquid assets may encourage them to make more sales transactions. The latter may lead some people to become even more concerned that the availability of money may cause them to spend on unnecessary, useless, and unintentional purchases.

Furthermore, in a questionnaire distributed to young students the present research found that consumption of several luxury goods such as cosmetics, jewelry or restaurant meals was accelerated significantly by holding more available cash. In contrast, other basic or necessary consumption goods were not affected positively by a higher availability of cash. The present study considers and seeks to statistically prove how students, who are aware of the positive impact of cash on luxury purchases, respond to luxury items in cash holding. They try to avoid holding cash and thus tend to spend relatively less on luxury items, whereas the opposite is true regarding purchase of basic items.

The present study seeks to theoretically modify the simple Baumol approach and statistically prove that while it does not distinguish between different kinds of transactions, it does not reflect the appropriate transaction for the money demand motive. If indeed young students are aware of their spontaneous purchasing behavior, they may decide voluntarily to reduce their cash balance for "precautionary" reasons, i.e. by avoiding cash availability. The present model examines this precautionary approach.

Bhaskara and Kumar (2011) estimate alternative characteristics for the demand for money in the U.S. during the period from 1960 to 2008 and examine its stability. In addition to the rate of interest introduced by Baumol in his original paper (1952) to capture the effects of the cost of holding money, they find that including trend and additional variables is useful and improves the stability of this relationship.

Based on their tests, they conclude that the demand for money in the U.S. has generally been stable except for a small change after 1997. Financial reforms seem to have reduced the demand for money on average by about $2 \%$ to $2.5 \%$ annually and the response to the cost of holding liquidity has remained the same at about 0.36 in both subsamples.

In this article, the original Baumol paper is modified due to other concerns by asserting that the cost of holding cash is minimized with the reduction of impulsive purchasing. With the consideration of this element, the article introduces a different and "new" modified Baumol equation.

The article begins by introducing the original Baumol equation (1952) in which the demand for money is affected positively by the value of a transaction; negatively by the interest rate that affects the transaction motive; and positively by the cost of each cash withdrawal that affects the balance of cash at each withdrawal.

The original Baumol equation is then modified in the following way. While the original Baumol equation does not at all consider the distinction between types of transactions, the modified equation includes two additional variables of basic and luxury purchases. The new modified Baumol equation improves the relationship between the demand for money as a dependent variable and affecting variables as independent variables.

According to the present approach, if people are indeed aware that availability of liquid payment tools such as cash in hand causes them to buy luxury items that are not necessarily important or required in "rational terms," then they will reduce these spontaneous transactions by holding less cash. The opposite can be expected with respect to basic goods that have higher utility values. These kinds of items may not be affected by the availability of cash in hand.

The demand for money by private individuals and consumers is complicated. The idea that liquid assets affect private consumption expenditure has been discussed in the literature for several decades (e.g. Zellner, 1975; Fisher et al., 1962; Modigliani and Brumberg, 1954).

More recently, Kalckreuth et al. (2014) focuson and emphasize the unique characteristics of cash. While not reflected in standard transaction cost measures, these characteristics nevertheless seem valuable to consumers, "Cash contains memory - the amount spent, and the remaining budget can easily be gathered by a glance into one's pocket" (p. 1779). A different approach suggests that using cash is a simple device for monitoring liquidity and controlling a budget either due to the high costs of overdraft or the need to avoid overspending.

Runnemark et al. (2015) indicate a similar understanding. When paying with cash, a purchaser can see how much money is deducted from a total amount, but with a credit card payment he cannot see how the money disappears. In this sense, paying with a card may feel less real and thus less painful. The conclusions of that paper are that cash makes it simpler to 
control spending since payments tend to be more transparent. In their paper, the authors mention the understanding that cash is immediate and not restricted in its purpose and location. They also indicate the possibility that individuals who do not carry enough cash on them have to incur the extra cost of using an automated teller machine (ATM) if they want to spend more. Thus, they explain one reason why spending might be lower with cash.

The approach in the present article contrasts with that presented by Kalckreuth et al. (2014) and Runnemark et al. (2015), which provides a similar explanation of why cash is still used for transactions despite a broad distribution of noncash payment instruments. In particular, they argue that a distinctive feature of cash - a glance into one's pocket - sends a signal reminding one of the remaining budget and past expenses and is helpful to some consumer behavior. Using payment survey data, the present research shows that consumers who need to maintain control over their remaining liquidity and have elevated costs of information processing complete a larger percentage of payments using cash, withdraw cash less often, and hold larger cash balances than other consumers.

Zellner et al. (1965) explore in greater detail the short-run consumption function. Their study concludes by explaining the role of liquid assets in determining consumption spending. The data supports the hypothesis that the holding of imbalanced liquid assets by consumers exerts a statistically and economically significant influence on consumption.

Chang et al. (2007) determine that an increased ratio of consumer purchases to cashable deposits increases the real cost of cash withdrawals. Recent papers of Badgaiyan and Verma (2014) and Amir et al. (2014) support these "findings" with respect to impulsive behavior.

Yun et al. (2011) discuss the difference in "mental satisfaction" when paying either with a credit card or with cash, and whether it may have an effect on consumer behavior. Based on questionnaires, they show that consumers believe the two payment options differ in both function and use. However, the difference does not generate significant variance in consumer price sensitivity and spontaneous and irrational buying according to the payment method used. Consumers do prefer, however, to buy "non-essential" goods with credit cards and to use cash for purchasing "essential goods."

In addition, Karbasivar and Yarahmadi (2011) show that there are more than emotional reactions involved. They analyze consumer impulse buying using window displays, credit cards, and promotional activities such as cash discounts and free products. Their research recommends that sellers and marketers allow ATMs in their shops and promote their use by customers.

In the following section, the present article develops a modification to the original Baumol equation.

\section{Model}

In the original Baumol model (1952) the demand for money for the transaction motive is affected positively by the monetary values of transactions, Y; and negatively by the interest rate, $r$, and the cash withdrawal activity, $b$. This leads to the well-known Baumol Equation $m=\sqrt{\frac{2 b Y}{r}}$.

Gonen et al. (2016) extend Baumol's basic model using the approach of behavioral economics that a gap exists between nominal monetary spending, Y, and the real value of those transactions. Some of the transactions include spending on basic and necessary items. These transactions have high value and are considered rational purchases. However, some other spending such as on luxury items (for example, cosmetics and jewelry) is often considered "spontaneous and impulsive" in nature. Availability of cash and other easy methods of payments (such as credit cards, gift cards, discount coupons, etc.) may encourage unnecessary and thus less valuable spending. Although the amount of spending on luxury items is in monetary terms the same as on basic and necessary items, in real terms some of the amount measures losses. To avoid these losses, the consumer decides to hold less available liquid assets such as money. As a result, it is expected that the additional factor of losses created by luxury purchases encourages a lower demand for money. By adding another factor to the analysis, one may expect a different and modified Baumol demand for money that is therefore referred to as a modified Baumol equation. The analysis below presents the new equation and afterwards investigates it empirically and statistically by comparing the new equation to the original Baumol equation and examining the data set. The question remains whether the new equation indeed better fits the real behavior of customers. The present study shows that ignoring the factor of money availability, such as the negative attitude towards holding money, leads to biased results of the original Baumol equation.

While in the original Baumol model the objective function of the customer is to minimize the cost of holding money with respect to the three parameters mentioned above: $\mathrm{Y}, \mathrm{r}$ and $\mathrm{b}$, we add $\delta$ to them. This parameter indicates the value of loss from transactions due to spontaneous use of available liquid money. Therefore, the new total cost function of holding money is: 


$$
\operatorname{Min} T C=b \cdot \frac{Y}{m}+r \cdot \frac{m}{2}+\delta\left(m-m_{0}\right)
$$

The right term of the right-hand side of the equation represents the idea that a minimal amount of $m_{0}$ is always required cash that is designated for very basic, necessary spending that can only be completed mostly in cash (such as purchase of a newspaper, payment for public transportation, ice cream or a soft drink, etc.).

Taking the derivate of $\mathrm{TC}$ with respect to $\mathrm{m}$ leads to the F.O.C. as follows:

$$
\frac{d T C}{d m}=\frac{r}{2}-\frac{b}{m^{2}}-\delta=0
$$

Thus,

$$
m^{2}=\frac{2 b Y}{\gamma-2 \delta}
$$

or

$$
m^{*}=\sqrt{\frac{2 b Y}{\gamma+2 \delta}}
$$

A high level of $\delta$ will encourage customers to hold a lower average level of money for transactions. Thus these customers will be inclined to withdraw less money more often for the sake of lower losses due to spontaneous purchasing. The following section considers the factors that positively affect spontaneous purchasing according to habits, age, gender, income and other socioeconomic variables, in order to build a profile of a typical customer who more likely has the modified demand for money.

\section{Data and Methodology}

This section begins with the statistical analysis to prove the modification of the Baumol equation.

\subsection{Data}

This study analyzes how individuals make decisions regarding their monthly monetary spending on consumption products using either of the Baumol equations. The study is based on 257 questionnaires that were distributed during the 2015-2016 academic year to students at two institutions of higher education in Israel, (Bar-Ilan University and Sha'arei Mishpat - The Academic Center of Law and Science). The structure of the questionnaire is discussed below. The statistical package SPSS 22 is used for statistical analysis of the data set.

\subsection{Questionnaire Design}

The research questionnaire contains the following three sections:

1. The first section includes six questions relating to the financial management history of the respondent. For example, "What is the number of months in which there was an overdraft in one or more of your checking accounts?" "During the past year, did you receive inquiries from the bank, such as a letter, a telephone call, or a meeting request, regarding deviations from your credit limit in one or more of your personal checking accounts at the bank?"

2. The second section is the questionnaire research base. In this section, twelve questions are asked about the way in which money is spent by the respondents. The respondents are presented with a number of categories of products such as food, clothing, cosmetics, jewelry and more, as well as with five possible methods of payment such as cash, credit card, debit card, etc.

The following is an example of a question in this chapter:

The respondent is asked to mark an $\mathrm{X}$ in a table, indicating the impact of the availability of money in his wallet on his tendency to buy more of the listed products.

The degree of influence is ranked in ascending order from 1 to 5 , where 1 indicates that availability of money significantly reduces the consumption of the product and 5 indicates that greater availability of money encourages the purchase of the product.

3. The third section contains questions related to the socioeconomic background of the customer. It includes items such as gender, age, marital status, income, and work status. 


\begin{tabular}{llllll}
\hline Factors & 1 & 2 & 3 & 4 & 5 \\
& $\begin{array}{l}\text { Strongly } \\
\text { reduces } \\
\text { consumption }\end{array}$ & $\begin{array}{l}\text { Moderately } \\
\text { reduces } \\
\text { consumption }\end{array}$ & $\begin{array}{l}\text { No } \\
\text { reduction or } \\
\text { increase in } \\
\text { consumption }\end{array}$ & $\begin{array}{l}\text { Moderately } \\
\text { Increases } \\
\text { consumption }\end{array}$ & $\begin{array}{l}\text { Strongly } \\
\text { increases } \\
\text { consumption }\end{array}$ \\
\hline Basic food & & & \\
Quality food & & & \\
Clothing and \\
footwear \\
Cosmetics \\
Detergents \\
Jewelry \\
Entertainment \\
and books
\end{tabular}

\subsection{Methodology}

The effects of socioeconomic characteristics on consumption of luxury items

The initial important presumption is that the availability of liquid assets such as cash in hand encourages the inclination of the representative customer to spend more on luxury goods. This claim requires some extended discussion about factors that affect the demand for luxury goods, and as a result implicitly affect the demand for money negatively.

As previously mentioned and further discussed below, in the present study a detailed questionnaire was distributed to students. The questionnaire references several luxury items, including among them jewelry, cosmetics or cultural goods, in order to derive the socioeconomic characteristics that influence the demands for these items.

Several linear regressions of the following variables were run as presented in the following equation:

$$
\begin{aligned}
\text { Luzury }= & \alpha+\gamma_{1} \text { Gender }+\gamma_{2} \text { Family }+\gamma_{3} \text { Age }+\gamma_{4} \text { Income }+ \\
& \gamma_{5} \text { Education }+\gamma_{6} \text { Employment }+\gamma_{7} \text { Religious }+\varepsilon
\end{aligned}
$$

For gender value, 1 indicates male and 0 indicates female.

For Family, 0 indicates unmarried and 1 indicates married.

For Age, the age of each customer is indicated.

For Income, the five income groups included are approximately 5 quintiles of the population.

For Education, 1 indicates graduation from high school.

For Education, 2 indicates a B.A. degree.

For Education, 3 indicates an M.A. degree.

For Employment, 1 indicates unemployed.

For Employment, 2 indicates employed, part-time.

For Employment, 3 indicates employed, full-time.

\subsection{Estimation of the Modified Baumol Equation}

In order to test the research hypotheses, the following econometric model was estimated:

$$
\mathrm{M}=\mathrm{C}+\beta_{1} \cdot \mathrm{Y}+\beta_{2} \cdot \mathrm{b}+\beta_{3} \cdot \mathrm{r}+\gamma \text { Luxury }
$$

where $\mathrm{C}$ is the constant. $\mathrm{Y}$ represents the five categorical income levels from 1-5. b represents the cost of each withdrawal. $r$ is the interest rate the respondent faces. Luxury is a variable containing three luxury products: cosmetics, jewelry and cultural goods.

The study uses a hierarchical regression in order to examine its contribution to the Baumol model. In the first stage, the original Baumol model is run according to the questionnaire. The second stage adds the luxury item and examines its contribution to the general model. 


\section{Results of the Regression}

\subsection{Descriptive Statistics}

As mentioned above, the sample includes 257 respondents. The detailed data set is given in Table 1 below.

Table 1. Descriptive statistics

\begin{tabular}{|c|c|c|}
\hline \multirow{2}{*}{ Gender } & Female & $54 \%$ \\
\hline & Male & $46 \%$ \\
\hline \multirow{2}{*}{ Family status } & Unmarried & $65.7 \%$ \\
\hline & Married & $34.3 \%$ \\
\hline \multirow{2}{*}{ Age Groups } & Up to 25 & $44.7 \%$ \\
\hline & Above 25 & $55.3 \%$ \\
\hline \multirow{3}{*}{ Number of children } & 0 & $86.7 \%$ \\
\hline & $1-2$ & $7.8 \%$ \\
\hline & Above 2 & $10.9 \%$ \\
\hline \multirow{2}{*}{ Income } & Up to 7000 & $56.3 \%$ \\
\hline & Above 7000 & $43.7 \%$ \\
\hline \multirow{3}{*}{ Education } & Basic Education & $45.0 \%$ \\
\hline & B.A. & $26.6 \%$ \\
\hline & M.A.and Ph.D. & $28.4 \%$ \\
\hline \multirow{3}{*}{ Employment status } & Unemployed* & $17.4 \%$ \\
\hline & Part-time work & $41.7 \%$ \\
\hline & Full-time work & $40.9 \%$ \\
\hline \multirow{5}{*}{ Employment area } & High-Tech & $24.3 \%$ \\
\hline & Security, and public & $16.7 \%$ \\
\hline & Industry & $15.3 \%$ \\
\hline & Money and finance & $10.4 \%$ \\
\hline & Other & $33.3 \%$ \\
\hline \multirow{3}{*}{ Religious Status } & Secular & $39.7 \%$ \\
\hline & Traditional & $35.9 \%$ \\
\hline & Orthodox & $24.5 \%$ \\
\hline
\end{tabular}

*Unemployed, Student and Soldier

$46 \%$ of the respondents are men and $54 \%$ are women, with an average age of 26.7. 34.3\% of the respondents are married and $65.7 \%$ are single. $86.7 \%$ of them have no children, $7.8 \%$ have one or two children, and $10.9 \%$ have more than 2 children. $90.4 \%$ of the respondents in the sample were born in Israel. From the religious perspective, $39.7 \%$ of them define themselves as secular, $35.9 \%$ as traditional and $24.5 \%$ as orthodox. $17.4 \%$ of the respondents are unemployed, $41.7 \%$ have part-time work and $40.9 \%$ have full-time work. $86.7 \%$ have served in the army. With regard to education, $45 \%$ of the respondents in the sample have basic education, $26.6 \%$ hold a bachelor's degree and $28.4 \%$ hold a graduate degree. $24.3 \%$ of the respondents work in high-tech; $16.7 \%$ work in security and public jobs; and $25.7 \%$ work in money, finance and industry.

\subsection{Regression Estimation of the Demand for Luxury}

In this section the demand for luxury items is derived with respect to several socioeconomic characteristics. In the original estimation several additional characteristics were used regarding religion, gender etc., but eventually the study found that only three variables indeed had values significant in affecting the demand for luxury. They are presented in Table 2. 
Table 2. Regression Estimation for Luxury

\begin{tabular}{|c|c|c|c|c|c|}
\hline & \multicolumn{2}{|c|}{ Unstandardized Coefficients } & \multirow{2}{*}{$\begin{array}{l}\text { Standardized Coefficients } \\
\text { Beta }\end{array}$} & \multirow{2}{*}{$\mathbf{t}$} & \multirow{2}{*}{ Sig. } \\
\hline & $\mathrm{B}$ & Std. Error & & & \\
\hline (Constant) & 10.17 & 0.69 & & 14.85 & 0.00 \\
\hline Family status & -1.14 & 0.37 & -0.24 & -3.04 & 0.00 \\
\hline Income & 0.02 & 0.01 & 0.14 & 1.76 & 0.08 \\
\hline Employment status & 0.38 & 0.25 & 0.11 & 1.52 & 0.09 \\
\hline
\end{tabular}

The results of Table 2 show that customers who are unmarried, single, and probably young adopt the attitude of spending relatively more on luxury. Since they have no family commitments or parenthood obligations, the luxury item has a larger share in the consumption bundle of singles. Families with children have a different ranking of importance such as spending more on food, clothing, etc., and thus are less inclined to also spend on luxuries. They therefore behave less spontaneously.

As expected, income level positively affects the consumption of luxury goods due to income elasticity that is greater than one. The third variable also positively affects the consumption of luxury goods. Accordingly, when a consumer has full-time work and most likely feels steady and secure in his employment position, he allows for spending on luxury items. A profile of luxury item consumers can be built on that basis. The next stage considers how spending more on luxury goods encourages a customer to reduce spontaneous luxury purchases by reducing the availability of cash in hand. This is examined in the following section.

\subsection{Regression Estimation of the Modified Baumol Equation}

The following discussion examines the "improvement" in the estimated modified Baumol equation compared to the original Baumol function. The latter Baumol equation only assumes that the demand for cash is affected positively by total transactions, negatively by the interest rates, and positively by the costs per cash withdrawal. In interviews with private customers, they claim that due to their human weakness for impulsive purchasing, another important factor is the avoidance of cash holding. The modified Baumol equation considers this factor. Cash that is more available leads people to waste their money on unnecessary goods such as luxuries. Thus, in order to create a good buffer that avoids wasteful behavior, they prefer to hold less available cash. As shown below, the preceding argument of customers is statistically and significantly justified and leads to an improvement in the demand function for money by the modified Baumol equation. Better correlation is gained by using the suggested modified version. For this purpose, the present research uses the hierarchic regression in Table 3 below, with two stages of analysis.

The first stage uses the three explanatory independent variables that were used by the original Baumol equation. The second stage adds the additional variable of luxury spending due to the availability of cash. It is a negative variable that reduces the inclination to hold cash. The results are shown in the two panels in Table 3.

Table 3. Hierarchical regression

Panel A - Model Summary

\begin{tabular}{lllll}
\hline \multirow{2}{*}{ Model } & \multirow{2}{*}{ R Square } & $\begin{array}{l}\text { Change Statistics } \\
\text { R Square Change }\end{array}$ & F Change & Sig. F Change \\
\hline Model 1- Original Baumol & 0.076 & 0.076 & 5.91 & 0.00 \\
Model 2- Modified Baumol & 0.092 & 0.016 & 3.74 & 0.05 \\
\hline
\end{tabular}


Panel B - Hierarchical regression

\begin{tabular}{|c|c|c|c|c|c|c|}
\hline \multirow[t]{2}{*}{ Model } & & \multicolumn{2}{|c|}{ Unstandardized Coefficients } & \multirow{2}{*}{$\begin{array}{l}\text { Standardized } \\
\text { Coefficients } \\
\text { Beta }\end{array}$} & \multirow[t]{2}{*}{$\mathbf{t}$} & \multirow[t]{2}{*}{ Sig. } \\
\hline & & B & Std. Error & & & \\
\hline \multirow{4}{*}{$\begin{array}{l}\text { Model } \\
\text { Baumol }\end{array}$} & (Constant) & 1840.26 & 2502.49 & & 0.74 & 0.46 \\
\hline & $\mathrm{Y}$ & 2915.99 & 1024.71 & 0.19 & 2.85 & 0.01 \\
\hline & $\mathrm{b}$ & 114.79 & 74.16 & 0.10 & 1.55 & 0.12 \\
\hline & $\mathrm{r}$ & -1548297.39 & 540411.18 & -0.19 & -2.87 & 0.01 \\
\hline \multirow{5}{*}{ Model 2- Modified Baumol } & (Constant) & 9849.34 & 4830.08 & & 2.04 & 0.04 \\
\hline & $\mathrm{Y}$ & 3120.00 & 1023.66 & 0.20 & 3.05 & 0.00 \\
\hline & $\mathrm{b}$ & 125.28 & 73.89 & 0.11 & 1.70 & 0.09 \\
\hline & $\mathrm{r}$ & -1682893.72 & 541473.40 & -0.21 & -3.11 & 0.00 \\
\hline & Luxury & -924.44 & 477.95 & -0.13 & -1.93 & 0.05 \\
\hline
\end{tabular}

Panel A illustrates the significance of each of the models: the original Baumol equation (model 1) as well as the modified Baumol equation (model 2).

As shown, the explained variance $\mathrm{R}^{2}$ grows when moving from model 1 to model 2 , from $\mathrm{R}^{2}$ of $7.6 \%$ to $9.2 \%$. Both models are significant, but the luxury variable contributes $1.6 \%$ more to the explained variance of $7.6 \%$. This result statistically improves the reliability of the modified results. Furthermore, by using Panel B the effect of the coefficients is also better in model 2. Without using our modification, the cost per withdrawal, $b$, negatively affects the demand for holding cash but this effect is not significant. However, the effect of cost per withdrawal is significant and negatively affects the demand for holding cash in the modified model in which luxury is implemented and has a negative and significant effect on the demand for money.

\section{Conclusions}

The paper recommends reconsideration of the original Baumol (1952) equation of the demand for money for transaction purposes. It suggests some modification to the basic and simplified approach used by Baumol. His historical "square root equation" includes two elements of the cash holding cost function: the interest yields on assets that are held as cash and the cost of each cash withdrawal. While several papers suggest different additional variables that may influence the original Baumol equation, one important aspect was not considered. The present modification includes other characteristics in the equation of the demand for money for transaction purposes. It distinguishes between the demand for money for basic and necessary purchases as compared with luxury items. We assume that the former items are less sensitive to money availability, while the latter may reflect more spontaneous purchases that are affected positively by the availability of cash in hand. This factor may influence the Baumol equation due to the customer concern that holding too much cash may lead to wasteful purchases. The present research develops a theoretical extension to the original equation and statistically improves the correlation between the original and the modified versions. Thus, the study offers an improved version of the Baumol equation. The statistical analysis suggests several conclusions supporting the approach that necessitates a more sophisticated way of dealing with the demand for money for the transaction motive. First, it shows that customers respond positively to cash availability when they spend more on luxury goods. This is prominent especially among unmarried and most likely young customers. Due to high-income elasticity, spontaneous purchasing is higher among wealthier customers and full-time workers who maintain a steady and secure employment position. Since such customers have a weakness for spontaneously and sometimes even carelessly buying luxury items, from their perspective they create a good and efficient buffer by decreasing the available cash in hand, thereby reducing or possibly even preventing their wasteful behavior. This element is introduced in this paper and leads to an improved and modified Baumol equation that is more reliable and more statistically significant than the original Baumol equation. 


\section{Reference}

Amir, F., Zahur, S. Y., Qureshi, A. N., Akbar, S. J., \& Amin, M. F. (2014). Impulsive buying behavior of women in apparel industry in Pakistan. International Journal of Management Sciences, 2(7), 296-314.

Badgaiyan, A. J., \& Anshul, V. (2014). Intrinsic factors affecting impulsive buying behavior - evidence from India. Journal of Retailing and Consumer Services, 21, 537-549. http://dx.doi.org/10.1016/j.jretconser.2014.04.003

Baumol, W. J. (1952). The transactions demand for cash: An inventory theoretic approach. Quarterly Journal of Economics, 66, 545-556. http://www.jstor.org/stable/1882104

Bhaskara, R. B., \& Saten, K. (2011). Is the US demand for money unstable? Applied Financial Economics, 21(17), 1263-1272. http://doi: 10.1080/09603107.2011.568395

Bounie, D., \& Rançois, A. (2008) Is Baumol's 'square root law' still relevant? Evidence from micro-level data. Applied Financial Economics, 18(13), 1091-1098. http://doi: 10.1080/09603100701367427

Chang, J-J., Chang, W-Y., Lai, C-C., \& Wang, P. (2007). Equilibrium dynamics in an endogenous growth model of money and banking. Journal of Money, Credit and Banking, 39(7), 1683-1710. http://www.jstor.org/stable/4494316

Fisher, F. M., Griliches, Z., \& Kaysen, C. (1962). The costs of automobile model changes since 1949. Journal of Political Economy, 70, 433-451.

Gonen, L. D., Weber, M., Tavor, T., \& Spiegel, U. (2016). A modified Baumol approach-optimal withdrawal and holding of cash liquid assets. Review of European Studies, 8(2), 8-21.

Kalckreuth, Ulf von, Schmidt, T., \& Stix, H. (2014). Using cash to monitor liquidity: implications for payments, currency demand, and withdrawal behavior. Journal of Money, Credit and Banking, 46(8), 1753-1785. http://dx.doi.org/10.1111/jmcb.12165

Karbasivar, A., \& Yarahmadi, H. (2011). Evaluating effective factors on consumer impulse buying behavior. Asian Journal of Business Management Studies, 2, 174-181. http://dx.doi.org/10.1108/EJM-03-2011-0110

Modigliani, F., \& Buumberg, R. (1954). Utility analysis and the consumption function: An interpretation of cross-section data. In K. K. Kurihara (Ed.), Post Keynesian Economics, 388-436. New Brunswick, NJ. Rutgers University Press.

Runnemark, E., Hedman, J., \& Xiao, X. (2015). Do consumers pay more using debit cards than cash? Electronic Commerce Research and Applications, 24(5), 285-291.

Whitesell, W. C. (1989). The demand for currency versus debit able accounts. Journal of Money, Credit, and Banking, 21, 246-251.

Yun, X., Xie, Q., \& Lei, M. (2011). A comparative analysis of consumer behavior with payments of shopping cards and cash. Beijing Information Science \& Technology, School of Economics and Management, 539-544.

Zellner, A., Huang, D. S., \& Chau, L. C. (1965). Further analysis of the short-run consumption function with emphasis on the role of liquid assets. Econometrica, 33, 571-581. http://www.jstor.org/stable/1911752

Zellner, A. (1975). Bayesian Analysis of Regression Error Terms. Journal of the American Statistical Association, 70, 138-144.

\section{Copyrights}

Copyright for this article is retained by the author(s), with first publication rights granted to the journal.

This is an open-access article distributed under the terms and conditions of the Creative Commons Attribution license (http://creativecommons.org/licenses/by/4.0/). 